\title{
Articles for a Special Issue of Public Organization Review (POR) on Corruption, Lack of Transparency and the Misuse of Public Funds in Times of Crisis
}

\author{
Ali Farazmand ${ }^{1} \cdot$ Elina De Simone ${ }^{2}$. Salvatore Capasso ${ }^{3}$. \\ Giuseppe Lucio Gaeta ${ }^{3}$
}

Published online: 1 June 2021

(c) Springer Science+Business Media, LLC, part of Springer Nature 2021

\section{Background}

When rent extraction and monitoring failures affects the citizens-government relationship (Lederman et al., 2005), room for corruption emerges. And the greater is the discretionary power of the public officials, the more likely they will be able to negotiate a bribe with stakeholders and "misuse public power for private gain" (Rose-Ackerman, 2008). And yet, despite a considerable bulk of empirical literature has found that corruption harms the economy, some questions remain unanswered on why and how this may occur (Capasso et al., 2019).

During these turbulent times, it is deemed necessary to promote theoretical and empirical investigations to unveil how corruption is dissolving accountability around the world due to an increased allocation of public money to offset the negative effects of the pandemic on the economies. In fact, these massive government interventions harm the accountability of public governance by reducing the transparency and monitoring of the decision-making process, which are important to unveil mismatches between the management of public funds and public needs and malpractice or irregularities (De Simone et al., 2017).

The implementation of policy solutions to overcome the crisis may entail significant monitoring problems as the set of priorities-that identify safety, subsistence and timeliness at the top- asks for the use of urgency instruments to provide the support measures. However, bypassing the standard regulatory calendar to accommodate the current government needs can be particularly risky in terms of frauds, as a weaker system of checks and balance may expose "system vulnerabilities" (Heald $\&$ Hodges, 2020).

\footnotetext{
Ali Farazmand

afarazma@fau.edu

1 Florida Atlantic University, Boca Raton, USA

2 Roma Tre University, Rome, Italy

3 University of Naples Parthenope, Napoli, Italy
} 
The lack of accountability may undermine the effectiveness of countries' recovery efforts and represents a fundamental issue in public financial management. International organizations such as the IMF and Transparency International emphasize the importance of adopting stricter anti-corruption measures to strengthen governance during COVID19 emergency. They monitor countries that have received support funds and financial assistance to check whether those programs include any anti-corruption measures.

For example, since a recent stream of literature has emphasized the importance of e-procurement to increase access to information and reduce corruption (LewisFaupel et al., 2016), European Union has created a COVID-19 dedicated page for tenders related to medical equipment needs "to facilitate access to tenders related to the COVID-19 pandemic". The objective is clearly to fight corruption by improving visibility and monitoring in the bidding process as bribery cases in the procurement process are regularly reported by the press in countries particularly hit by the pandemic like Italy.

Hence, this symposium calls for theoretical works on the increased risks of corruption and related contrasting measures in times of crisis and it also elicits empirical papers on the issue containing analyses at macro and industry levels. Both comparative papers (across time, countries, government levels, or policy sectors) and single case studies are particularly appreciated.

Papers can be theoretical or empirical, explanatory or descriptive, but they should have a clear conceptual and theoretical basis and meet appropriate methodological standards. The symposium welcomes researchers from different disciplines, from public administration to management and accounting research, economics and political science, sociological and organization studies, public policy, and beyond.

\section{Examples of Suitable Topics for the Special Issue}

- The nature of corruption problems in times of pandemic and their impacts across different levels of government, sectors, and contexts

- Corruption and public procurement

- Measurement challenges in detecting corruption: data and methods.

- Transparency initiatives to improve accountability of public decision-making in times of Covid-19

- Characteristics of anti-corruption measures as part of the response to combat the outbreak: an overview

- Effectiveness of anticorruption tools, policies, and interventions.

- Public administration and corruption: advancing theory and empirics

- Transparency and anti-corruption agenda: taking stock, looking ahea

\section{Proposals and Manuscripts}

Proposals should clearly present:

(1) a descriptive title; 
(2) a statement of theme and purpose that includes a problem statement;

(3) research questions, including descriptive and explanatory parts;

(4) a theoretical/literature basic, briefly outlining central theories and concepts;

(5) the 'originality' and significance of the paper;

(6) a brief methodology statement that includes, for example, sources of data and tools and methods; and

(7) the paper's added value including potential contributions to knowledge (generalizability). Proposals should not exceed the 2-page limit.

Completed manuscripts should not exceed 30 pages double spaced (or 8000 words), inclusive of all tables, figures, and charts. APA style with third person writing is required. Style guidelines are on the POR website.

\section{Timetable to Publication}

Interested scholars are invited to submit proposals of approximately 800 to 1000 words POR by June 30, 2021. Proposing authors will be notified by July 15-20, 2021.

Draft manuscripts of accepted proposals are due by October 31, 2021.

Authors of draft manuscripts will receive a preliminary review by December 31 , 2021 from the Guest Editors; they will include:

(1) a recommendation to complete the manuscript likely with some suggested revisions;

(2) a recommendation to revise and resubmit with more substantive revisions; or

(3) a decision that the manuscript will not be accepted - consider submitting it to a different journal. A review with a (1) or (2) recommendation does not guarantee acceptance of the final manuscript.

Final manuscripts are due February 28, 2022. Final manuscripts will be double-blind reviewed during March and April 2022.

Final reviews and decisions will be posted on POR's Editorial Manager's Site by April 30, 2022.

The Special Issue will be published in POR: Online by May 31, 2022 and in print, in June 2022.

Proposals and manuscripts should be submitted to the Editor-in-Chief of POR, or any of the Guest editors-see below.

Questions about the substance or process for proposals, manuscripts, or the Special Issue should be submitted to a Guest Editor.

\section{References}

Capasso, S., Goel, R. K., \& Saunoris, J. W. (2019). Is it the gums, teeth or the bite? Effectiveness of dimensions of enforcement in curbing corruption. Economics of Governance, 20(4), 329-369. 
De Simone, E., Gaeta, G. L., \& Mourão, P. R. (2017). The impact of fiscal transparency on corruption: An empirical analysis based on longitudinal data. The BE Journal of Economic Analysis \& Policy, 17(4).

Heald, D., \& Hodges, R. (2020). The accounting, budgeting and fiscal impact of COVID-19 on the United Kingdom. Journal of Public Budgeting, Accounting \& Financial Management, 32(5), 785-795.

Lederman, D., Loayza, N. V., \& Soares, R. R. (2005). Accountability and corruption: Political institutions matter. Economics \& politics, 17(1), 1-35.

Lewis-Faupel, S., Neggers, Y., Olken, B. A., \& Pande, R. (2016). Can electronic procurement improve infrastructure provision? Evidence from public works in India and Indonesia. American Economic Journal: Economic Policy, 8(3), 258-283.

Rose-Ackerman S. (2008). Corruption. In: Readings in Public Choice and Constitutional Political Economy. Springer, Boston, MA.

Publisher's Note Springer Nature remains neutral with regard to jurisdictional claims in published maps and institutional affiliations. 